\title{
Transformasi Spirit Konferensi Asia Afrika pada Keterlibatan Warga Negara Muda sebagai Pembinaan Identitas Kebangsaan
}

\author{
Silvia Rahmelia ${ }^{1}$, Endang Danial Ar ${ }^{2}$ \\ 1Sekolah Tinggi Agama Kristen Negeri Palangka Raya, Indonesia \\ ${ }^{2}$ Departemen Pendidikan Kewarganegaraan Fakultas Ilmu Pengetahuan Sosial Universitas \\ Pendidikan Indonesia, Indonesia \\ 1silviarahmelia@gmail.com
}

\begin{abstract}
ABSTRAK
Spirit solidaritas sebagai nilai historis Konferensi Asia Afrika (KAA) sepatutnya diteladani dan diinternalisasikan dalam implementasi pengembangan karakter warga negara muda. Keterlibatan yang solid dan efektif melalui pemaknaan sejarah perjuangan bangsa sebagai nilai dasar inisiasi warga negara muda menjadi bentuk keterlibatan dan solidaritas yang positif. Solidaritas yang positif selayaknya mampu meminimalisir penyimpangan makna solidaritas yang banyak terjadi pada generasi muda. Tujuan penelitian ini adalah menggambarkan analisis transformasi peran keterlibatan warga negara muda dalam perwujudan hak, kewajiban, tanggung jawab, serta terlibat aktif pada level lokal, nasional, regional, maupun internasional dengan tidak meninggalkan identitas kebangsaan. Penelitian ini menggunakan pendekatan kualitatif dengan metode studi kasus yang dilakukan dengan teknik pengumpulan data berupa wawancara, observasi, dan studi dokumentasi. Hasil penelitian menunjukkan bahwa spirit perjuangan bangsa pada jaman dahulu serta komitmen kebangsaan terwujud dalam format baru keterlibatan warga negara muda pada sebuah komunitas, yaitu Sahabat Museum Konferensi Asia Afrika (SMKAA). Spirit solidaritas KAA dinilai masih relevan hingga saat ini dan bertransformasi menjadi semangat terbarukan berupa kebersamaan, semangat perjuangan, melepaskan subjektivitas, dan semangat bersatu. SMKAA melalui program kegiatannya telah mentransformasikan sejarah KAA yang bersifat abstrak menjadi konkret dengan penyebarluasan nilai-nilai KAA, yaitu kesetaraan, kerjasama, dan hidup berdampingan. Keterlibatan warga negara muda hari ini perlu dilandasi pula oleh spirit untuk mengkaji sejarah perjuangan bangsa Indonesia. Memperkuat dan menumbuhkan literasi dalam spirit solidaritas akan menjadi modal yang penting. Pola pikir spirit solidaritas (the past as the memories) perlu ditumbuhkan kembali saat ini untuk meraih harapanharapan ke depan (the future as expecatation).
\end{abstract}

Kata Kunci: Konferensi Asia Afrika, keterlibatan warga negara muda, spirit solidaritas

\begin{abstract}
The spirit of solidarity as an Asian-African Conference (KAA) historical value should be exemplified and internalized in the form of youth character development. Solid and effective involvement through understanding the nation's historical struggle as the basic value of youth initiation becomes a form of positive engagement and solidarity. Positive solidarity should be able to minimize the meaning deviation of solidarity that is often the case among younger generation. This study aims to describe the analysis of role transformation in youth involvement in the realizations of rights, obligations, and responsibilities, as well as participating in local, national, regional, or international levels by not leaving their national identity. The research used qualitative approach with a case study method. Data was collected
\end{abstract}


by interviews, observations, and documentation studies. The result shows that the nation's spirit of past struggle and commitment were manifested in a new format of youth involvement in the Sahabat Museum Konferensi Asia Afrika (SMKAA) community. The spirit of Asian African Conference's solidarity is considered still relevant nowdays and transforming into a renewed spirit of togetherness, struggle, relinquishing subjectivity and united spirit. SMKAA, through its program, has transformed the KAA's abstract history into concrete dissemination of values, i.e equality, cooperation, and coexistence. Youth involvement nowdays needs to be based on the spirit to examine the nation's historical struggle, to strengthen and develop literacy, which will be an important asset. The spirit of solidarity mindset needs to be regenerated today to achieve future expectations.

Keywords: Asian African Conference, young citizen involvement, solidarity spirit

This work is licensed under the Creative Commons Attribution-ShareAlike 4.0 International License. (C2019 by the author(s).

Received: July 232019

Revised: August 132019

Accepted: September 92019

\section{PENDAHULUAN}

Mencermati Rencana Pembangunan Jangka Panjang Nasional (RPJPN) Tahun 2005-2025, terdapat fokus pembangunan yang menekankan pada kualitas sumber daya manusia serta kemampuan IPTEK (Undang-Undang Nomor 17 Tahun 2007 tentang Rencana Pembangunan Jangka Panjang Nasional (RPJPN) Tahun 2005-2025, 2007). Memasuki era industri 4.0, Indonesia perlu memantapkan pengembangan mental warga negara muda agar lebih kompeten dan ikut terlibat aktif dalam kompetisi regional. Dalam rangka mewujudkan visi yang telah diusung dalam RPJPN, seyogyanya pemerintah berperan sebagai pengatur kebijakan sekaligus merealisasikan cita-cita nasional untuk mencerdaskan kehidupan bangsa, menyelenggarakan pendidikan terbaik dan merata bagi seluruh warga negara. Namun di samping itu penyelenggaraan pendidikan harus memperlakukan, memfasilitasi, dan mendorong peserta didik menjadi subjek pembelajar sepanjang hayat (lifelong learning). Di mana dalam hal ini pembelajar termasuk di dalamnya warga negara muda haruslah menyesuaikan diri dan merespon tantangan dengan spirit baru dengan tetap menjaga identitas kebangsaan yang telah menjadi jati dirinya. Kecanggihan teknologi yang ada saat ini tidak lantas membawa warga negara muda pada kontaminasi budaya luar yang kebanyakan belum sesuai dengan adab ketimuran. Terlebih lagi menurut Cress (2012), pengetahuan dan wawasan selayaknya bersatu dalam keterlibatan yang sadar dan peduli, yang demikianlah yang dapat dikategorikan sebagai warga negara yang kompeten.

Pemahaman mengenai filterisasi dan penggunaan kecanggihan teknologi serta kontaminasi budaya global memerlukan peran pendidikan, sebab pada hakikatnya pendidikan merupakan proses pembudayaan, pemberdayaan, dan pembentukan karakter. Maka dari itu cita-cita pembangunan nasional yang dituangkan dalam berbagai perencanaan haruslah diselaraskan dengan perkembangan lingkungan subjek pembelajar. Tentunya hal ini juga bertolak dari Visi Kemendikbud 2019 yakni “terbentuknya insan serta ekosistem pendidikan dan 
kebudayaan yang berkarakter dengan berlandaskan gotong royong" (Kementerian Pendidikan dan Kebudayaan, 2015) Mengacu pada visi tersebut maka sistem pendidikan di Indonesia harus dapat menghasilkan insan Indonesia cerdas dan kompetitif (insan kamil/insan paripurna).

Manfaat yang timbul dari keterlibatan warga negara sebagai bagian dari visi pendidikan akan timbul lebih seimbang dan holistik pada kompetensi warga negara muda jika ditopang oleh pembelajaran yang efektif dan aktualisasi yang juga efektif di masyarakat. Persepsi dan pemahaman mengenai situasi yang menyeluruh juga penting untuk merangsang keterlibatan masyarakat dan sikap konstruktif seperti dikatakan Sandu, O.N. (2015) pada penelitiannya mengenai stereotip dan prasangka pada situasi masyarakat yang dikembangkan menjadi kerangka pengembangan civic engagement di persekolahan. Sebagai gambaran dari pembahasan penelitian mengenai kompetensi warga negara muda dengan meramu spirit solidaritas, keterlibatan, dan identitas kebangsaan.

Pembangunan kualitas sumber daya manusia khususnya warga negara muda merupakan suatu keharusan, mengingat dari tahun ke tahun data hasil survey mengenai kenakalan remaja semakin mengkhawatirkan. Kenyataan tersebut kontradiktif dengan visi pemerintah untuk mengembangkan kualitas SDM. Data hasil survey yang dilakukan oleh Badan Kependudukan dan Keluarga Berencana Nasional (BKKBN) menyatakan bahwa ada banyak jenis kenakalan remaja yang sekarang ini marak terjadi. Di antara berbagai kenakalan remaja adalah seks pra nikah dan kehamilan tidak diinginkan (perilaku seks bebas dan ketidaktahuan tentang penggunaan kondom memicu tingginya angka ini). Selanjutnya yaitu aborsi, yang mana dari total 2,4 juta, 700-800 ribu di antaranya dilakukan oleh remaja. Selain itu jumlah remaja yang meninggal sangat tinggi, yaitu 17 ribu per tahun, 1.417 per bulan, 47 per hari perempuan meninggal karena komplikasi kehamilan dan persalinan. Jumlah penderita HIV/AIDS mencapai 1283 kasus, dan diperkirakan 52 ribu terinfeksi (fenomena gunung es). Faktanya $70 \%$ dari keseluruhan penderita HIV/ AIDS adalah remaja. Miras dan narkoba semakin marak penggunaannya, dan tidak jarang sampai menimbulkan kecanduan yang semakin sulit disembuhkan (Badan Kependudukan dan Keluarga Berencana Nasional, 2014).

Penyimpangan norma dan moral yang ditunjukkan sekelompok remaja kebanyakan ialah perilaku agresivitas yang dihasilkan dari komunikasi kelompok. Kebiasaan generasi muda untuk berkumpul dan membicarakan banyak hal membuat komunikasi yang terjalin dari sebuah kelompok menjadi solid. Dari situ akan mudah menularkan karakter positif maupun karakter negatif. Oleh karena itu, pembentukan karakter dalam rangka pembangunan kualitas warga negara muda perlu diinisiasi dari perkumpulan yang solid dan menularkan spirit positif.

Peneliti mengambil salah satu makna sejarah perjuangan bangsa bangsa sebagai variabel dalam menginisiasi keterlibatan warga negara muda. Peneliti beranggapan bahwa dalam rangka membenahi perilaku generasi muda tersebut tidak cukup jika hanya mengandalkan penerapan mata pelajaran formal di sekolah saja. Dibutuhkan alternatif lain untuk menyokong gerakan pembangunan karakter melalui lingkungan masyarakat. Baik itu digali dari peristiwa-peristiwa inspiratif 
maupun sosok teladan di masyarakat yang menjadi contoh model pembinaan karakter di luar institusi formal. Perlu beberapa tahapan dalam rangka menumbuhkan spirit dalam diri manusia, terutama generasi muda. Salah satu program tentang menumbuhkan spirit nasionalisme yang berlandaskan nilai-nilai Pancasila pada generasi muda, yaitu program Indonesia-Korea Youth Exchange Program (IKYEP) terbukti dapat lebih memupuk jiwa nasionalisme dan prinsip kebhinekaan (Haris, et.al. 2015, hlm. 182).

Spirit solidaritas yang menjadi nilai inti dari Konferensi Asia Afrika (KAA) 60 tahun lalu mampu menginspirasi warga negara anggota Asia Afrika untuk senantiasa memelihara nilai-nilai kerjasama dan semangat hidup berdampingan secara damai dimulai dari lingkungan terkecil. Menurut Kepala Museum Asia Afrika Thomas Ardian Siregar, "energi kehidupan muncul melalui penghayatan akan nilai-nilai yang terkandung dalam sejarah khususnya peringatan Konferensi Asia Afrika. Hal itu tercermin dalam semangat solidaritas dan persahabatan," (Dzulfikri Amri Rahman, 2016). Suatu bangsa adalah masyarakat solidaritas dalam skala besar. Solidaritas tersebut disebabkan oleh pengorbanan yang telah diberikan pada masa lalu dan bersedia berkorban untuk masa depan. "Penghayatan masa lalu diwujudkan pada masa kini di dalam suatu kesepakatan bersama untuk melanjutkan kehidupan bersama"(Tulus, 2014).

Merasa memiliki nasib yang sama dan solidaritas yang tinggi merupakan bagian yang tidak terpisahkan dari identitas bangsa. Membawa spirit itu kembali membutuhkan generasi muda sebagai seorang yang keratif dan inovatif dalam menciptakan perubahan dan tranformasi yang bernilai. Orang muda sebagaimana digambarkan Checkoway (2011) dalam penelitiannya, bahwa mereka mengembangkan keterampilan praktis untuk keterlibatan masyarakat dalam iklim demokratis dewasa ini. Mereka belajar bagaimana untuk membawa orang bersama-sama, menilai kondisi, menetapkan tujuan, dan merumuskan rencana untuk implementasi. Karena lokasi sosial mereka, bagaimanapun, mereka belajar tentang ras dan kelas sebagai faktor dalam demokrasi dan dengan demikian, menjadi sadar identitas sosial dan budaya mereka sendiri, dan orang-orang yang berbeda dari diri mereka sendiri. Semangat solidaritas KAA ini diharapkan mampu menginspirasi keterlibatan warga negara muda. Dunia di luar sekolah adalah laboratorium untuk pembelajaran yang sesungguhnya. Apabila ditafsirkan, pendapat di atas melingkupi pemahaman bahwa pendidikan di masa depan harus relevan dengan upaya untuk mengembangkan pengetahuan dan pemahaman yang demokratis, kesadaran sebagai seorang warga negara terhadap perspektif global, keterampilan dalam pemecahan masalah di lingkungan sekitar, pelayanan terhadap masyarakat yang kesemuanya muncul dalam kerangka keterlibatan sebagai warga negara (civic engagement).

Adapun kajian ini bermuara pada pemikiran tentang transformasi spirit dari peristiwa historis Konferensi Asia Afrika (KAA) yang patut diteladani dan direlevansikan dengan kehidupan warga negara muda dewasa ini. Peristiwa KAA dipilih sebagai titik tolak mengingat peristiwa tersebut merupakan penanda penting dalam sejarah negara-negara Asia Afrika saat mempersatukan diri menuju kemerdekaan, memperbaiki kondisi ekonomi, dan memajukan perdamaian. Sebagaimana 
dikatakan dalam catatan Roeslan Abdulgani dalam buku The Bandung Connection, “...generasi mendatang akan hidup di abad ke-21. Mereka harus pandai membaca pertanda zaman dan menemukan cara-cara mengatasi permasalahan agar bangsa mereka tetap jaya. Mereka tidak perlu dan tidak harus meniru kondisi kami di masa perjuangan, karena jauh berbeda. Tapi tirulah semangatnya" (Abdulgani, 1988).

Penelitian ini bertujuan memberikan gambaran dan alternatif sudut pandang dalam ranah aktualisasi keilmuan PKn. Khususnya dalam praktik komunitas sebagai bagian dari ilmu kewarganegaraan. Pola pengembangan civic engagement yang dihasilkan sebagai bagian yang tidak terpisahkan dari penelitian ini diharapkan menjadi refrensi untuk pola partisipasi warga negara muda dalam ranah lainnya. Di samping itu dari penelitian ini diharapkan timbul masukan untuk pembelajaran PKn agar dapat menginternalisasikan pemahaman 'teaching world society' yang berarti di era globalisasi ini guru maupun dosen harus memposisikan diri sebagai fasilitator yang mengajar untuk warga dunia, di mana peserta didik sendiri sebagai calon warga negara/masyarakat dunia, nantinya diharapkan terlibat secara aktif dan bertanggung jawab baik pada taraf lokal, nasional, regional, maupun internasional, baik dalam dunia nyata maupun dunia maya. Tidak lupa bahwa keterlibatan warga negara yang dimaksud dalam skala global sekalipun sedianya tetap memiliki titik tolak pada local genius dan national identity.

\section{METODE}

Pendekatan kualitatif dengan metode studi kasus mengacu pada rasionalisasi dan asumsi dasar bahwa data yang ingin dihasilkan adalah data akurat dan mendalam yang menggambarkan proses keterlibatan warga negara muda pada SMKAA yang diinisiasi dari peristiwa KAA, kemudian bagaimana proses tersebut dapat dijadikan sebagai upaya pembinaan identitas kebangsaan. Lokasi penelitian yaitu sekretariat Sahabat Museum Konperensi Asia Afrika (SMKAA) bertempat satu atap dengan kantor MKAA tepatnya di Jalan Asia Afrika No. 65 yang berdampingan dengan Gedung Merdeka di Kota Bandung. Adapun partisipan/informan dalam penelitian ini adalah anggota komunitas Sahabat Museum Asia Afrika (SMKAA) dan saksi sejarah/tokoh yang terlibat langsung pada peristiwa KAA, dalam hal ini Prof. Dr. H.M. Nu'man Somantri sebagai saksi hidup peristiwa KAA sekaligus Ketua Senat IKIP yang tergabung dalam Tentara Pelajar serta turut terlibat mempersiapkan segala sesuatu untuk para delegasi Indonesia di KAA.

Pengumpulan data dilakukan dengan menggunakan teknik wawancara secara mendalam, observasi, dan studi dokumentasi. Observasi dalam penelitian ini menitikberatkan pada proses keterlibatan warga negara muda di SMKAA dalam bentuk kegiatan. Wawancara digali berdasarkan kapasitas narasumber untuk memposisikan data secara tepat dan akurat pada bagian pembahasan. Studi dokumentasi dilakukan karena data atau dokumen yang akan dibutuhkan dalam penelitian ini mencakup pula pada rancangan program, pola pelaksanaan program dalam komunitas, foto, keanggotaan, dan sebagainya. Peneliti menggunakan teknik analisis data yang mengacu pada langkah-langkah yang dipakai Miles dan Huberman untuk mengurai data dengan melakukan tahapan (1) reduksi data, (2) sajian data, (3) penarikan kesimpulan serta verifikasi. Peneliti menggunakan teknik 
analisis data mengacu pada langkah-langkah yang dipakai Miles dan Huberman untuk mengurai data berupa indikator keterlibatan warga negara muda yang didorong oleh spirit solidaritas Asia Afrika.

\section{HASIL DAN PEMBAHASAN}

\section{Transformasi Spirit Solidaritas KAA yang Menginisiasi Keterlibatan Warga Negara Muda}

Spirit solidaritas yang lahir sebagai intisari dari sejarah Konferensi Asia Afrika (KAA) telah menginspirasi keterlibatan warga negara muda. Setidaknya terdapat beberapa temuan penelitian yang mengarah pada peranan spirit solidaritas tersebut. Temuan ini didasarkan pada observasi, wawancara, dan studi dokumentasi yang dilakukan secara berkelanjutan terhadap subjek penelitian. Menurut saksi sejarah yang pernah dilibatkan dalam persiapan KAA, Prof. Dr. H. M. Nu'man Somantri, spirit solidaritas itu bermakna kebersamaan, merasa bersaudara, semangat perjuangan tanpa mempertimbangkan kesukuan, agama, dan kepentingan. Senada dengan pendapat Gearey (2015) yang mengatakan "Solidarity describes an "existential" community of those who experience a common fate and whose association organizes resources towards common ends. Solidaritas menjelaskan 'komunitas eksistensial' dari orang-orang yang mengalami nasib yang sama dan yang asosiasi mengatur sumber menuju tujuan bersama.

Kepentingan subjektif dilepaskan, semangat bersatu yang dikedepankan. Di samping itu menurut beliau, spirit ini tidak dapat dipisahkan dari kehidupan saat ini. Spirit KAA terutama solidaritas tumbuh seiring kecintaan kita terhadap sejarah perjuangan bangsa dan kebangkitan negara-negara dunia ketiga. Tentunya hal ini banyak menginspirasi kaum muda, kaum terpelajar yang tidak lepas mempelajari sejarah perjuangan bangsa. Terlebih lagi kaum muda dipersiapkan untuk terjun dalam masyarakat abad ke-21. Semangat KAA itu terbarukan, mendorong generasi muda untuk terlibat sikap sukarela, tanpa pamrih, gotong royong, dan kerjasama yang murni. Spirit itu bisa tumbuh jika ditanam secara bersama-sama, terlihat ketika sedang bekerja sama, sehingga akan muncul jiwa, semangat, ruh, dan keinginan yang kuat. Dengan demikian titik tolak pembahasan awal adalah kenyataan bergesernya makna solidaritas di kalangan generasi muda ke arah solidaritas yang negatif sebagaimana dikatakan Hadiswi dan Suminar (2013) dan Wicaksono (2012), kemudian spirit solidaritas ternyata mampu menginspirasi warga negara anggota Asia Afrika untuk senantiasa memelihara nilai-nilai kerjasama dan semangat hidup berdampingan secara damai dimulai dari lingkungan terkecil.

Di samping itu keterlibatan warga negara muda yang kian global dan transparan semestinya tidak menghilangkan nilai-nilai historis dan identitas kebangsaan Indonesia. Seperti dikatakan bahwa pengembangan generasi muda dengan sendirinya harus diarahkan untuk meningkatkan kemampuan dari setiap pemuda Indonesia untuk berperan sebagai transformator, sebagai penerus cita-cita proklamasi dan pelestari pancasila dan Undang-Undang Dasar 1945 (Gafur, 1982).

Menurut Prof. Dr. H. M. Nu'man Somantri yang juga adalah pakar Pendidikan Kewarganegaraan, spirit solidaritas ini dapat berperan besar untuk membentuk warga negara muda jika dikombinasikan dengan pembelajaran PKn 
yang tidak hanya mengandalkan didactic teaching (ceramah saja), namun juga mengaplikasikan reflective teaching dan value/judgement teaching. Spirit itu bisa tumbuh ketika warga negara muda (siswa/mahasiswa) berinteraksi dengan baik di luar dan di dalam lingkungan kelas. Ketiga pembelajaran PKn yaitu didactic, reflective, dan value teaching harus dikombinasikan agar siswa dapat terlibat dan tumbuh spirit nya. Masa depan akan dipenuhi isu-isu kontroversial. Maka menumbuhkan spirit itu bukan hanya sekedar menumbuhkan saja, namun harus dilihat konteksnya hari ini yang dihadapi adalah bagaimana mengatasi kemiskinan, liberalisasi, dan intoleransi. Solidaritas yang didasarkan atas rasa persaudaraan dan kebersamaan erat maknanya dengan solidaritas mekanis sebagaimana diungkapkan Durkheim, yang mana solidaritas tersebut didasarkan pula atas kepercayaan dan kesetiakawanan serta diikat oleh hati nurani kolektif (conscience collective) (Sunarto, 1993). Sebab pada hakikatnya manusia bersifat solidaristik karena mereka memiliki nilai-nilai bersama yang diperkuat berbagai ritual. Konsep solidaritasnya pun berhubungan dengan identifikasi manusia dan kebutuhan berkelompok (Scott, 2011). Kecocokan dan kesamaan nasib sebagai warga negara Asia Afrika menciptakan solidaritas antar anggota SMKAA yang notabene berbeda-beda. Disamping itu rentang usia yang bervariasi di SMKAA membuat hubungan antar generasi menjadi lebih efektif dalam mengatasi gejala depresi (Lee, et. al, 2015, hlm. 1425). Hal ini dibenarkan salah satu anggota SMKAA yang menjadikan kegiatan di SMKAA sebagai pengisi waktu luang dan refreshment dari padatnya jadwal kuliah.

Kemudian menurut Desmond Satria Adrian, S.S., M.Si. PIC (Person in Charge) Ketua Museum KAA sekaligus Edukator dan Pembina SMKAA, makna dari KAA itu tidak bisa ditolak keberadaan dan peranannya. Karena tercantum dalam amanat konstitusi Alinea 4 Pembukaan Undang-Undang Dasar 1945 “...melindungi segenap bangsa Indonesia dan seluruh tumpah darah Indonesia dan untuk memajukan kesejahteraan umum, mencerdaskan kehidupan bangsa, dan ikut melaksanakan ketertiban dunia yang berdasarkan kemerdekaan, perdamaian abadi dan keadilan sosial". Kemudian pada Alinea pertama terdapat kalimat "kemerdekaan adalah hak segala bangsa". KAA adalah merupakan cita-cita solidaritas bangsa kulit berwarna yang senasib sepenanggungan. "Spirit solidaritas tentu penting untuk ditumbuhkan kembali", demikian menurut Desmond Satria Adrian. Namun peranan spirit tersebut terhadap keterlibatan warga negara muda perlu dilihat faktanya bahwa generasi muda kita, seperti kebanyakan orang, kesulitan memahami sejarah perjuangan bangsa. Maka dari itu Museum Asia Afrika mengintisari sejarah KAA dan Dasasila Bandung menjadi tiga nilai yang disebut nilai-nilai KAA. Adapun nilai-nilai KAA tersebut ialah:

1. Kesetaraan (Equality), yaitu egaliter, atau bersifat sama, sederajat.

2. Kerjasama (Cooperation). Jika sudah setara, maka bekerja sama baik itu antar bangsa atau individu.

3. Hidup berdampingan dengan damai (Peaceful Co-Existence). Setelah mampu bekerja sama dan saling menghormati, maka hiduplah berdampingan secara damai.

Ketiga nilai tersebut sebetulnya mencerminkan hubungan internasional yang 
dihasilkan dari Konferensi Asia Afrika. Spirit solidaritas menjadi penting karena manfaatnya mungkin tidak bisa dirasakan hari ini, tapi beberapa tahun kemudian ketika mereka (orang asing) pulang ke daerahnya mereka akan memiliki sense of ownership terhadap Indonesia (mereka yang mendapat beasiswa dari pemerintah Indonesia). Kemudian bagi generasi muda di sini, mereka akan mampu bekerja sama dan memiliki jejaring dengan dunia internasional, terutama negara-negara bangsa Asia Afrika. Partisipasi publik dan pengembangan komunitas di masyarakat saat ini menjadi sebagian manfaat yang dapat dirasakan. Keduanya menjadi bagian dari inisiasi pemberdayaan masyarakat yang melahirkan hal baru di era digital dan knowledge management. Adanya diseminasi ilmu pengetahuan melalui website SMKAA secara tidak langsung mengindikasikan perkembangan kompetensi warga negara. Sebagaimana pernyataan Boulianne (2016) yang mengungkapkan bahwa menggunakan media sosial dalam hal keterlibatan warga negara menjadikan warga negara muda melek terhadap apa yang terjadi di dunia, dan dapat membangun kesadaran warga negara.

Keterlibatan warga negara muda hari ini perlu dilandasi pula oleh spirit untuk mengkaji sejarah perjuangan bangsa Indonesia. Memperkuat dan menumbuhkan literasi dalam spirit solidaritas akan menjadi modal yang penting, sebab spirit dalam bekerja sama harus pula didasari oleh pengetahuan dan wawasan yang mumpuni. Juga harus disadari bahwa bangsa Asia dan Afrika menjadi bangsa yang terjajah karena jauh dari ilmu pengetahuan sehingga mudah dikelabui oleh bangsa imperialis kolonialis. Hal ini sedikit banyak telah menginspirasi gerakan baru generasi muda untuk bangkit meningkatkan budaya literasi di tengah spirit yang menggebu-gebu. "Hari ini kita jauh dari ke-Indonesiaan kita karena literasi kita rendah, karena sejarah perjuangan bangsa kita tidak bisa kita baca, karena pola komunikasi yang berbeda". Demikian kata Desmond Satria Adrian. Tinjauan lain mengenai karakteristik solidaritas ini dapat dikaji melalui pendapat Manatschal dan Freitag (2014) dalam penelitiannya yang mengatakan bahwa solidaritas yang didominasi inisiatif individu atau yang dimotivasi oleh pertimbangan strategis dapat mengakibatkan pencapaian yang benar-benar membantu pada jenis solidaritas yang terfokus dalam hal membantu beberapa kelompok.

Temuan penelitian tentang spirit solidaritas yang menginspirasi keterlibatan warga negara muda di SMKAA diperkuat pula oleh Alfaqi yang menyatakan bahwa sikap solidaritas muncul ketika individu merasa cocok sehingga melahirkan sebuah kesepakatan bersama untuk berkomitmen dalam satu tujuan (Mifdal Zusron Alfaqi, 2015). Kecocokan dan kesamaan nasib sebagai warga negara Asia Afrika menciptakan solidaritas antar anggota SMKAA yang notabene berbeda-beda. SMKAA menganut sistem gotong royong dan kesukarelaan (volunteerism) dalam pelibatan warga negara muda. Kesukarelaan sebagaimana penelitian Morimoto dan Friedland (2013) dikategorikan sebagai salah satu indikator keterlibatan; diperkuat oleh penelitian Duke (2012) bahwa sebagian besar remaja (82,5\%), berusia 12 sampai 17 tahun, biasanya terlibat dalam kegiatan sukarela atau pelayanan masyarakat.

Spirit solidaritas yang diintisari dari nilai-nilai KAA menginspirasi keterlibatan warga negara muda melalui semangat yang terbarukan, yaitu 
kebersamaan, bersaudara, semangat perjuangan, melepaskan subjektivitas, dan semangat bersatu. Literasi sebagai unsur tambahan yang sangat menunjang akan menjaga warga negara muda untuk tidak kehilangan wawasan ketika terlibat aktif baik di dalam dan diluar lingkungan pendidikan formal. Jika di dalam lingkungan formal seperti sekolah, maka pembelajaran yang didapatkannya akan sarat dengan refleksi dan nilai positif, sementara jika di luar lingkungan formal, ia akan mampu berpartisipasi dan mengembangkan diri di dalam komunitas maupun masyarakat berbekal spirit dan pengetahuan yang mumpuni.

\section{Gambar 1. Transformasi Spirit KAA dalam Keterlibatan Warga Negara Muda}

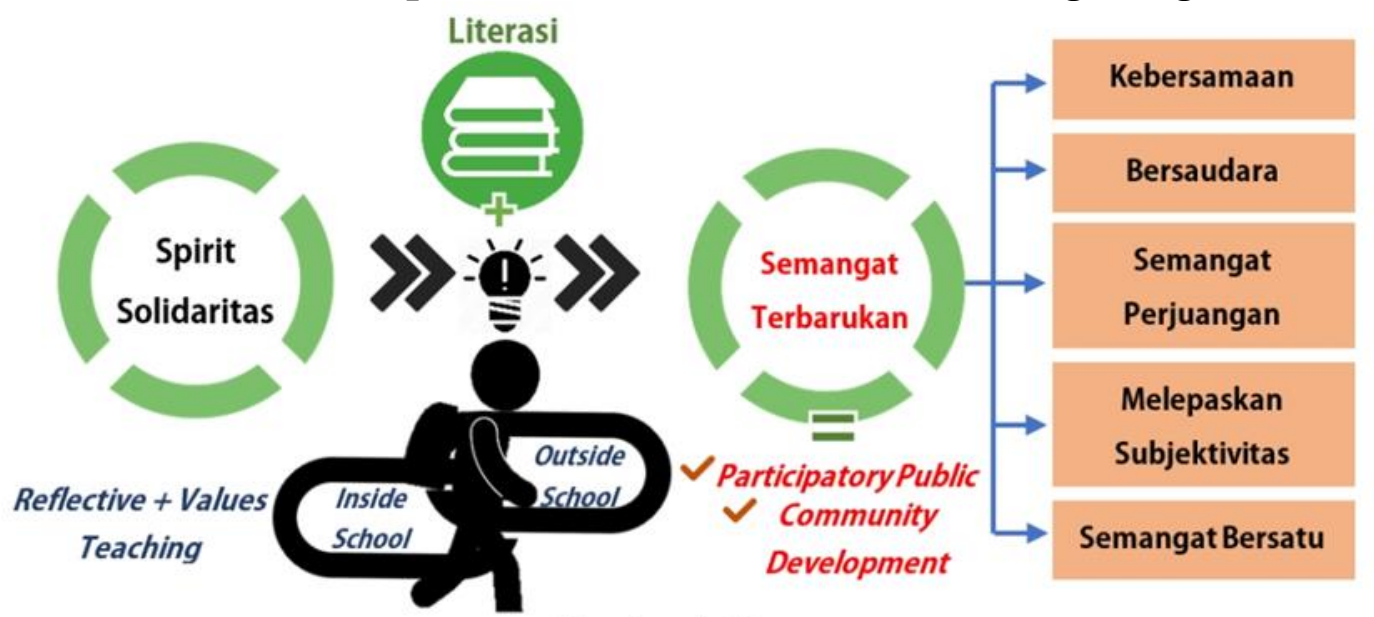

Sumber: Diolah peneliti dari referensi dan hasil penelitian (2017)

Inside school yang dimaksud pada Gambar 1 menggambarkan kondisi pembelajaran yang perlu direvitalisasi dengan reflective teaching method untuk mendukung outside school yang mengarah pada keterlibatan. Revitalisasi dimaksudkan ke arah informal dan non formal dengan melibatkan siswa pada komunitas-komunitas kemasyarakatan agar turut serta mengembangkan kerangka negara demokrasi, sebab pembelajaran yang berkualitas akan berproses menolong peserta didik meraih kecakapan hidup yang dibutuhkan untuk menyongsong warga negara abad ke-21 seperti halnya kecakapan berpikir kritis, penyelesaian masalah, kemampuan berkomunikasi, berkolaborasi, kreatifitas, inisiatif dan inovatif (Gordon \& McConnell, 2014). Hal tersebut didukung oleh fakta bahwa praktik yang dilakukan di sekolah menganggap kepekaan dan kegiatan yang berkaitan dengan dorongan pada tanggung jawab warga negara diperkuat dengan beberapa praktik di luar sekolah seperti halnya keterlibatan di komunitas. Guru yang mengajarkan tentang civic engagement pun tidak akan terlepas dari isu kontroversial yang dibahasnya, dengan demikian betul kiranya jika reflective teaching menjadi pendekatan yang penting dalam mendukung pembelajaran yang mengarahkan pada keterlibatan warga negara muda untuk merealisasi tujuan to be reflective citizen (Kawashima-Ginsberg, 2015).

\section{Spirit KAA yang Bertransformasi pada Format Baru Keterlibatan Warga Negara Muda}

Program di SMKAA dituangkan menjadi kegiatan yang tersebar dalam klab- 
klab dan mitra SMKAA, mulai dari klab literasi, seni, budaya, broadcasting, keterampilan, hingga edukasi. Terdapat 13 klab dan dua mitra yang merupakan bagian yang terintegrasi dengan SMKAA. Di SMKAA, wujud keterlibatan menjadi nyata dilakukan dengan do action, turun langsung dengan tindakan nyata, tidak lagi menggunakan format seperti seminar sebagai bentuk diseminasi pengetahuan maupun wadah diskusi. Hal itu sudah lama ditinggalkan. SMKAA menganut sistem gotong royong dan kesukarelaan (volunteerism) dalam pelibatan warga negara muda.

Keterlibatan warga negara muda yang dinilai merupakan hal yang esensial dalam membentuk sistem kemasyarakatan dan pemerintahan yang baik (Kavanaugh \& Karen M. Hult, 2011) didukung pernyataan bahwa keterlibatan melebihi sekedar partisipasi biasa; di dalamnya ada tanggung jawab dalam mengemban nilai, isu sosial, hingga sikap menghargai perbedaan (Hauptmann, 2005; Jacoby, 2009). Maka dari itu peneliti menganggap bahwa keterlibatan warga negara memang perlu dikaji lebih lanjut dengan melihat keterkaitannya dengan berbagai konsep Pendidikan Kewarganegaraan dari berbagai sisi.

Spirit KAA, terutama solidaritas, tumbuh seiring kecintaan kita terhadap sejarah perjuangan bangsa dan kebangkitan negara-negara dunia ketiga. Semangat KAA itu terbarukan, mendorong generasi muda untuk terlibat sikap sukarela, tanpa pamrih, gotong royong, dan kerjasama yang murni. Pola pikir bahwa spirit solidaritas (the past as the memories) perlu ditumbuhkan kembali hari ini (the present) untuk meraih harapan-harapan ke depan (the future as expecatation), sebab bentukbentuk solidaritas gotong royong dan kerjasama yang terbangun di masa lalu menjadi semangat yang terbarukan pada hari ini dan dinilai relevan dengan spirit KAA (Shadily, 1993).

Mengidentifikasi peran spirit solidaritas KAA dalam menginspirasi keterlibatan warga negara muda di Kota Bandung adalah salah satu kunci untuk menumbuhkan kembali spirit solidaritas. Penting untuk diketahui sejauh mana spirit tersebut menginspirasi mereka sehingga patut dan layak untuk ditumbuhkan kembali. Di samping itu nilai dari solidaritas berbeda-beda sebagaimana penelitian Paskov, M. (2016) yang mengindikasikan bahwa solidaritas bisa berarti penting tetapi juga bisa jadi hanya fungsi reputasi. Hal ini membuat spirit solidaritas KAA perlu digali secara khusus. Spirit solidaritas yang lahir sebagai intisari sejarah KAA telah menginspirasi keterlibatan warga negara muda. Setidaknya terdapat beberapa temuan penelitian yang mengarah pada peranan spirit solidaritas tersebut.

Keterlibatan warga negara muda di SMKAA yang terinspirasi dari peristiwa KAA telah menumbuhkan kebersamaan dan komitmen hingga akhirnya tercapai keselarasan (Soekanto, 2014) untuk sama-sama berjuang memperlihatkan citra positif Indonesia di mata internasional. Spirit yang berarti ruh, jiwa, napas (Merriam, 1983; Nasional, 2007; Sarwono, 1986) mendasari setiap tindakan manusia, perilaku psikologis terbuka yang disebut motif (Tamami, 2011). Keterlibatan warga negara muda di SMKAA termasuk kategori motif berafiliasi menurut McClelland (Walgito, 2010).

Kerjasama dan kesetaraan di dalam keterlibatan itu merupakan aspek yang relatif konstan yang akan sedikit demi sedikit menumbuhkan spirit solidaritas yang 
diharapkan (Gaby, 2016). Adapun ketiga nilai tersebut di atas sebetulnya mencerminkan hubungan internasional yang dihasilkan dari Konferensi Asia Afrika. Spirit solidaritas menjadi penting karena manfaatnya mungkin tidak bisa dirasakan hari ini, tapi beberapa tahun kemudian. Konteks kecil nya, manfaatnya ialah participatory public dan community development yang mungkin dapat dirasakan hari ini. Adapun community development sendiri termasuk pada participation skill yang diungkapkan Center of Civic Education (CCE) (Winataputra \& Budimansyah, 2007). Menekankan pada keterlibatan dan partisipasi warga negara dalam permasalahanpermasalahan kemasyarakatan, serta berkontribusi untuk pengembangan karakter warga negara dalam organisasi merupakan karakteristik dari citizenship education (Cogan \& Derricott, 2000; Wahab \& Sapriya, 2011).

Bagian yang juga bersejarah dari Konferensi Asia Afrika, yang melatarbelakangi spirit solidaritas keterlibatan warga negara muda, adalah sepotong surat dari Roeslan Abdulgani dalam bukunya A Bandung Connection, yang berisi penggalan kutipan:

Lihatlah apa yang telah diperbuat oleh bapak-bapak kalian dulu. Mereka tetap berpegang kepada sumber moral, yakni ajaran agama dan ajaran leluhur. Saya selalu bilang kepada generasi muda bahwa mereka tidak perlu dan tidak harus meniru kondisi kami di masa perjuangan, karena jauh berbeda. Tapi tirulah semangatnya (Abdulgani, 1988).

Maka dari itu menumbuhkan spirit solidaritas KAA pada keterlibatan warga negara muda menjadi penting, sebab pada hakikatnya generasi muda menghadapi tantangan dan permasalahan yang berbeda dengan generasi pejuang zaman dulu, perjuangannya tidak dapat disamakan, tetapi semangatnya patut ditiru. Kontekstualisme ini berarti bagaimana membawa kembali semangat KAA dewasa ini dengan kehadiran generasi muda sebagai modal pembangunan.

Mengeksplorasi program yang dilaksanakan SMKAA sebagai bentuk keterlibatan warga negara muda dalam menumbuhkan spirit solidaritas adalah salah satu tujuan agar transformasi yang dimaksud dapat kentara terlihat dan terbukti dalam penelitian ini. Desmond Satria Adrian, S.S., M.Si. mengatakan SMKAA dalam ilmu komunikasi telah mentransfomasi komunikan (masyarakat sebagai sasaran edukasi SMKAA) menjadi komunikator. Komunikator adalah individu yang memproduksi informasi, komunikan yang menerima informasi. Keterlibatan warga negara dengan mengkombinasikan pengetahuan, keterampilan, dan nilai-nilai seperti transformasi yang dilakukan SMKAA ini merupakan makna keterlibatan warga negara sebagai make a difference in the civic life (Ehrlich, 2000).

SMKAA menganut sistem gotong royong dan kesukarelaan (volunteerism) dalam pelibatan warga negara muda. Kesukarelaan dikategorikan sebagai salah satu indikator keterlibatan (Friedland \& Morimoto Lewis, 2013). Selanjutnya SMKAA dengan berbagai program yang bergerak di tiap klab merefleksikan sebuah pengelolaan ilmu pengetahuan (knowledge management) untuk memproduksi dan menyebarluaskannya. Dedikasi semacam ini membutuhkan komitmen yang kuat dari para anggota SMKAA untuk menyelenggarakan setiap kegiatan dengan lancar dan efektif. Knowledge management sendiri dapat dikategorikan sebagai unsur lifelong 
learning sebab di manapun dan kapanpun seseorang atau sekelompok orang dapat mengolah ilmu pengetahuan, termasuk di SMKAA. Disamping itu telah dijelaskan bahwa lifelong learning akan mentransfer sikap dan perilaku keterlibatan warga negara yang lebih luas (Cameron \& Scot, 2015).

SMKAA telah terbukti mengakomodir keinginan generasi muda terhadap suatu perubahan melalui kegiatan yang nyata. SMKAA mampu mengubah paradigma museum sebagai objek wisata yang minim pengunjung melalui night at museum. Program SMKAA ini dicetuskan oleh para relawan SMKAA untuk mengedukasi masyarakat agar lebih menghargai keberadaan museum. Kegiatan yang dikemas sedemikian rupa, ditambah daya tarik suasana di sekitar Gedung Merdeka pada malam hari mampu menarik minat masyarakat untuk mengunjungi museum. Masyarakat yang pada hari biasa tidak dapat mengunjungi museum dikarenakan padatnya aktivitas, dengan adanya night at museum mereka dapat meluangkan waktu sambil setidaknya berjalan-jalan di sekeliling lokasi museum. Dengan mengunjungi, melihat-lihat, dan membaca, masyarakat yang tadinya tidak tahu menjadi tahu, dari yang tahu menjadi lebih paham dan mampu menyebarluaskan inti dari keberadaan museum KAA itu sendiri.

Dari contoh di atas dapat dilihat bahwa perubahan bukan tentang ukuran besar kecilnya, namun proses di balik perubahan itu. Perubahan yang digagas oleh warga negara muda, sekecil apapun itu, menjadi pijakan dalam mengaktualisasikan dirinya, menguji kemampuannya, mengembangkan kompetensi yang ada di dalam dirinya, memperluas wawasan (knowledge), mengasah keterampilan (skill), dan membiasakan hal-hal positif (disposition). Sebagaimana penelitian yang menyajikan format baru dalam keterlibatan warga negara muda melalui focus group format yang mana format ini menghasilkan pemberdayaan di kalangan pemuda, dengan manfaat dapat mengembangkan keterampilan peserta dalam mengedepankan ide-ide, memvalidasinya (Savage \& Estes, 2015). Format focus group format ini juga senada dengan model yang dikembangkan Kavanaugh, Carroll, Rosson, Reese, and Zin yang menggambarkan group membership dalam suatu organisasi atau komunitas dapat menimbulkan sense of collective efficacy yang mana akan berimplikasi pada aktivitas pelibatan (civic engagement) (Kavanaugh \& Karen M. Hult, 2011). Sense of collective efficacy merupakan salah satu unsur civic skill (Be able to collaborate, build consensus and take collective action to address community issues) (Gordon \& McConnell, 2014).

Kemudian format lain dikembangkan melalui pendekatan GUIC (Growing Up in Cities) yang merupakan salah satu yang paling sering digunakan untuk mempelajari bagaimana anak-anak dan pemuda menggunakan ruang publik untuk perencanaan dan pengembangan masyarakat. Satu lagi ialah penelitian yang telah membuktikan melalui temuan penelitiannya bahwa format crowdfunding atau penggalangan dana dapat menunjang keterlibatan warga negara. Penulis dalam hal ini memandang bahwa format baru yang terus dikembangkan untuk wadah aktualisasi diri terutama bagi warga negara muda yang sedang dalam tahap perkembangan berpikir kritis, sangat penting, menimbang hal tersebut dapat memberikan pilihan pada kesesuaian format atau wadah keterlibatan dengan minat yang dimiliki, sehingga tidak terkesan dipaksakan pada wadah yang telah ada. 
Sebab alangkah baiknya jika minat yang baik tumbuh pada wadah yang tepat (Abdillah, 2015; Santo, Ferguson, \& Trippe, 2010).

Keterlibatan warga negara muda akan berdampak pada kompetensi warga negara yang dimiliki. Dalam kasus ini, terkait spirit solidaritas KAA yang telah menghasilkan semangat terbarukan pada diri warga negara muda untuk berkontribusi aktif, memberikan sumbangsih secara sukarela demi suatu perubahan atau pergerakan, berdampak pada kompetensi mereka sebagai warga negara. Sesuai dengan penelitian bahwa keterlibatan warga negara dan pengalaman kerelawanan mendorong pembangunan generasi muda yang positif (Bhangaokar \& Mehta, 2012). Pemanfaatan generasi muda dalam aktivitas kerelawanan dan keterlibatan warga negara secara umum akan berpengaruh pada peningkatan kompetensi diri dan pergeseran persepsi diri disertai dengan perubahan sosial-moral. Kemudian penelitian lain menyepakati bahwa pelayanan pada komunitas akan berdampak pada sikap kerelawanan atau lebih jauh lagi pada keterlibatan warga negara yang lebih umum (Brown, Pancer, \& D., 2013).

\section{SIMPULAN}

Setelah melalui tahapan deskripsi hasil penelitian, temuan penelitian, hingga pembahasan, analisis dari keseluruhan bagian tersebut dirangkum peneliti menjadi prosposisi atau generalisasi guna membentuk gagasan atau simpulan umum dari hasil penelitian, diantaranya spirit solidaritas Konferensi Asia Afrika masih relevan hingga saat ini, melihat temuan penelitian di lapangan yang mengarah pada semangat terbarukan dari Konferensi Asia Afrika yang mampu menginspirasi warga negara muda; warga negara muda sepatutnya menggali semangat perjuangan pada jaman dahulu, meniru, dan mengadopsinya dalam rangka menghadapi tantangan global yang kerapkali menghilangkan identitas kebangsaan; sahabat Museum Konferensi Asia Afrika (SMKAA) merupakan wahana keterlibatan warga negara muda yang menggelorakan nilai-nilai KAA, yaitu kesetaraan (equality), kerjasama (cooperation), dan hidup damai berdampingan (peaceful co-existence); proses pelibatan yang sesungguhnya mengandung proses transformasi nilai-nilai yang abstrak dan intangible menjadi sebuah program yang konkret dan tangible, sehingga melahirkan aksi nyata (do action); tren keterlibatan warga negara muda selayaknya berada pada koridor identitas kebangsaan, sehingga melahirkan rasa kepemilikan terhadap Indonesia (sense of ownership) dan rasa kebanggan (pride of Indonesia).

Spirit yang merupakan ruh atau jiwa cenderung diawali oleh sebuah kesadaran dalam kerangka filsafat the past as the memories, the present as the truth, the future as the expectation, sehingga setelah kesadaran itu akan muncul motivasi dan perubahan. Hal ini akan berdampak pada paradigma bahwa warga negara muda yang hari ini terklasifikasi dalam generasi $\mathrm{Z}$ atau generasi milenial cenderung berafiliasi dalam format baru dimana wadah tersebut dapat mengembangkan wawasan, literasi, juga karakter yang dimilikinya. Persepsi jangka Panjang mengenai keberhasilan pendidikan adalah ketika mampu menyeimbangkan antara pembelajaran dalam institusi formal dan non formal, yang mana keduanya akan bermuara pada "to be harmonious, to be reflective, and to be participating citizen". Tentunya warga negara muda dituntut untuk mampu menjaga identitas kebangsaan 
dan komitmen terhadap Pancasila dalam setiap interaksi yang melibatkan unsur di luar bahasa, budaya, dan bangsa Indonesia. Dengan demikian keterlibatan, partisipasi, dan kontribusi akan tersublimasi pada sikap dan perilaku warga negara yang lepas dari subjektivitas dalam bekerjasama.

\section{REFERENSI}

Abdillah, F. (2015). Pengembangan Keterlibatan Warga Negara Melalui Penggalangan Dana Online untuk Memupuk Tanggung Jawab Sosial Mahasiswa: Studi Grounded Theory Proyek Crowdfunding Bantu Baca di Kitabisa.com.

Abdulgani, R. (1988). The Bandung Connection The Asia-Africa Conference in Bandung in 1955.

Badan Kependudukan dan Keluarga Berencana Nasional. (2014). Kondisi Remaja Indonesia Saat ini. In Badan Kependudukan dan Keluarga Berencana Nasional. Retrieved from http:/ / bkkbn.go.id

Bhangaokar, R., \& Mehta, D. (2012). Youth Civic Engagement in India: A Case in Point. Journal Psychology and Developing Societies, 24(1). https:/ / doi.org/https:/ / doi.org/10.1177/097133361102400102

Boulianne, S. (2016). Online News, Civic Awareness, and Engagement in Civic and Political Life. Journal New Media and Society, 18(9), 1840-1856. Retrieved from: http://www.nms.sagepub.com.

Brown, A. H., Pancer, S. M., \& D., S. (2013). Creating Effective Civic Engagement Policy for Adolescents: Quantitative and Qualitative Evaluations of Compulsory Community Service. Journal of Adolescent Research, 29(1), 120-154. Retrieved from https://doi.org/10.1177/0743558413502532

Cameron, W., \& Scot, Y. (2015). Developing Social Responsibility and Political Engagement: Assessing the Aggregate Impacts of University Civic Engagement on Associated Attitudes and Behaviors. Education, Citizenship and Social Justice, 10(3). Retrieved from https:/ / eric.ed.gov / ?id=EJ1077903

Checkoway, B. (2011). Education for Democracy by Young People in Community Based Organization. Journal Youth E Society, 45(3),389-403.

Cogan, J. J., \& Derricott, R. (2000). Citizenship for the 21st Century: An International Perspective on Education. London: Psychology Press.

Cress, C. M. (2012). Civic Engagement and Student Success: Leveraging Multiple Degrees of Achievement. Diversity and Democracy, 15(3), 1-23. Washington DC: Association of American Colleges and University.

Denzin, N., Lincoln, \& Yvonna, S. (2009). Handbook of Qualitative Research. Yogyakarta: Pustaka Pelajar.

Duke, N. N., et al (2012). Adult Perception of Neoghborhood: Links to Youth Engagement. Journal Youth E Society, 44(3), 408-430.

Dzulfikri Amri Rahman. (2016). Energi Kehidupan dalam KAA Semangat Solidaritas dan Persahabatan. Retrieved from http:/ / bandungekspres.co.id/2016/energi-kehidupan-dalam-kaa-semangatsolidaritas-dan-persahabatan/

Ehrlich, T. (2000). Civic Responsibility and Higher Education. Washingtom DC: Oryx Express. 
62 | Silvia Rahmelia, Endang Danial Ar

Transformasi Spirit Konferensi...

Friedland, S. A., \& Morimoto Lewis. (2013). Cultivating Success: Youth Achievement, Capital and Civic Engagement in the Contemporary United States. Sociological Perspectives. Retrieved from https:// doi.org/10.1525/sop.2013.56.4.523

Gaby, S. (2016). The Civic Engagement Gap(s): Youth Participation and Inequality From 1976 to 2009. Journal Youth \& Society, 45(3), 1-24. https:// doi.org/10.1177/0044118X16678155

Gafur, A. (1982). Kebijakan Nasional Kepemudaan di Indonesia. Jakarta: Departemen Pendidikan dan Kebudayaan R.I.

Gearey, A. (2015). Welfare, Community, and Solidarity. Journal of Law, Culture, and the Humanities, 11(3), 340-348. Retrieved from: http:/ / www.lch.sagepub.co.

Gordon, D., \& McConnell, H. J. D. (2014). Revitalizing K-12 Civic Learning in California. California: California Bar Foundation.

Hadiswi, P., dan Suminar, J. R. (2013). Konstruksi Sosial Anggota Geng Motor di Kota Bandung. Jurnal Kajian Komunikasi, 1(1), 1-10.

Haris, R. M., et. al. (2015). Analisis Komunikasi Antar Etnis di Kalangan Muda Nusantara dalam Membangun Spirit Nasionalisme Menuju Kerjasama Antar Bangsa Melalui Indonesia-Korea Youth Exchange Program (IKYEP). Journal Kareba. Vol 4(2). Hlm. 172-188.

Hauptmann, J. (2005). Toward Theory of Civic Engagement. Parkville: Park University International Center For Civic Engagement.

Jacoby, B. (2009). Civic Engagement in Higher Education: Concepts and Practices. San Francisco: Jossey-Bass.

Kavanaugh, B. J. K. A. L., \& Karen M. Hult. (2011). Civic Engagement and Internet Use in Local Governance: Hierarchical Linear Models for Understanding the Role of Local Community Groups. Administration and Society. Retrieved from https:// doi.org/10.1177/0095399711413873

Kawashima-Ginsberg, P. L. K. (2015). Deeper Learning Research Series Civic Education and Deeper Learning. Boston: Jobs For The Future.Org.

Kementerian Pendidikan dan Kebudayaan. (2015). RENCANA STRATEGIS KEMENTERIAN PENDIDIKAN DAN KEBUDAYAAN.

Lee, C.Y, et.al. (2015). Integenerational Solidarity and Individual Adjusment During Emerging Adulthood. Journal of Family Issues, 37(10), 1412-1432. Retrieved from: jfi.sagepub.com.

Manatschal and Freitag, M. (2014). Respirocity and Voluntering. Journal Rationality and Society, 26(2), 208-235.

Merriam, W. (1983). Merriam-Webster's Pocket Dictionary. Massachusetts: Merriam Webster Incorporated Oxford.

Mifdal Zusron Alfaqi. (2015). Memahami Indonesia Melalui Perspektif Nasionalisme, Politik Identitas, serta Solidaritas. Jurnal Pertahanan Nasional, 28(2), 111-116. Retrieved from journal.um.ac.id/index.php/jppk/article/view/5451/2120\%0A

Moleong, L. J. (2007). Metodologi Penelitian Kualitatif. Bandung: PT Remaja Rosda Karya Offset. 
Nasional, D. P. (2007). Kamus Besar Bahasa Indonesia. Jakarta: Balai Pustaka.

Paskov, M. (2016). Is Solidarity less Important and Less Functional in Egalitarian Context?. Acta Sociologica, 59(1), 3-18. Retrieved from: http://asj.sagepub.com.

Sandu, O.N. (2015). Civic and Intercultural Education: A Means for Community Development and Attitude Change. Journal of Information Development, 30(4), 1-6. Retrieved from: http:/ / sgo.sagepub.com.

Santo, C. A., Ferguson, N., \& Trippe, A. (2010). Engaging Urban Youth through Technology: The Youth Neighborhood Mapping Initiative. Journal of Planning Education and Research, 30(1), 52-65. Retrieved from https:/ / doi.org/10.1177/0739456X10366427

Sarwono, S. W. (1986). Berkenalan dengan Aliran-aliran dan Tokoh-tokoh Psikologi. Jakarta: Bulan Bintang.

Savage, M. P., \& Estes, W. T. (2015). Concept Reintegration for Youth Focus Group Engagement and Empowerment. Journal of Qualitative Social Work. Retrieved from https:/ / doi.org/10.1177/1473325014547066

Scott, J. (2011). Sosiologi: The Key Concept. Jakarta: Rajawali Press.

Shadily, H. (1993). Sosiologi untuk Masyarakat Indonesia. Jakarta: PT Rineka Cipta.

Soekanto, S. (2014). Sosiologi Suatu Pengantar. Jakarta: PT Raja Grafindo Persada.

Sunarto, K. (1993). Pengantar Sosiologi. Jakarta: Penerbit Fakultas Ekonomi Universitas Indonesia.

Tamami. (2011). Psikologi Tasawuf. Bandung: Pustaka Setia.

Tulus, M. (2014). Konfigurasi Pendidikan Karakter Berparadigma Kebangsaan; Usaha Meneguhkan Identitas Diri Bangsa dari Kungkungan Arus Globalisasi. Jurnal El-Hikmah Tarbiyah, IX(2), 257-279. Retrieved from id.portalgaruda.org.

Undang-Undang Nomor 17 Tahun 2007 tentang Rencana Pembangunan Jangka Panjang Nasional (RPJPN) Tahun 2005-2025. , (2007).

Wahab, A. A., \& Sapriya. (2011). Teori dan Landasan PKn. Bandung: Alfabeta.

Walgito, B. (2010). Pengantar Psikologi Umum. Yogyakarta: CV Andi Offset.

Winataputra, U. S., \& Budimansyah, D. (2007). Civic Education: Konteks, Landasan, Bahan Ajar dan Kultur Kelas. Bandung: Program Studi Pendidikan Kewarganegaraan.

Woodside, A. G. (2010). Case Study Research: Theory, Methods, and Practice. Emerald. 